\title{
THE CHURCH AND THE SUB-CULTURE ${ }^{1}$
}

Canon William E. Thompson,

St. Agnes Anglican Church, Nassau.

(Citations from Hebrew \& Greek: Genesis $1: 1$; St. John 1:1)

The funny sounds just heard are an attempt at reading the Bible in the original language from which it has come down to us over the past nineteen hundred years. The first sounds are from the old Testament.

Reference to the sounds is not to show the listeners that the lecturer remembers a smattering of Hebrew and Greek from his university days. It is to demonstrate in a dramatic way the inevitable link between the Church and the culture. The Bible, the most important tool in the hand of the Church, and by "church" I mean any religious group whose approach to meaning involves the Bible and Jesus Christ as it attempts its saving work, is a culture document, reflecting the culture of the Mediterranean world in which the Church was born. It may be said that, Christianity sprang out of Judaism, took root in the Roman empire, and used the Greek language as its medium of propagation. In short, the Church was greatly affected by the culture which pervaded the Mediterranean area more than 2,000 years ago. The connection between religion and culture is an inevitable one, and is particularly so in the case of Christianity because of the Incarnation principle, that on-going affirmation of God's engagement with humanity in time and in history through Jesus Christ.

Before going any further, having accepted the link between the Church and culture as inevitable, I should now like to try to define culture. I shall then apply this definition to the sub-culture, since the difference is merely one of emphasis not fact, in fidelity to the theme of this talk, "The Church and the sub-culture".

What, then, is culture? Guyana's Arthur J. Seymour, in a collection of papers on Caribhean Christian concerns entitled With Eyes Wide Open, (1973:104) defines culture as "the basic assumptions, attitudes and beliefs and customs, the web of meaning and history that we call the background of a people". U.S.A.'s Harvey Cox, in a book on folk religion called The Seduction of the Spirit,
(1973:306) delineates culture as "a combination of ideas, values and images". Although Seymour's definition emphasises the background impact of culture while cox throws into relief the foreground dynamics of culture, both agree in pointing out that culture makes a society tick. Indeed, Alland, the anthropologist, has built a complete anthropology around this theme in opposition to Ardery's emphasis on the possession of territory as a vital force in human evolution. Those of us who remember our High School Latin will have noticed the link with "colo", the word to describe the process of growth and development in the plant world. Culture, then, is a necessary element in any society. It, however, will take on many forms, for ideas, values and images - to follow Cox - are too dynamic to be constrained by any particular mould. These moulds are always the products of the interaction between history and ecology, to say the least. Some elements in the particular cultural mould will be more valued and projected than others. These will constitute what I should like to term the "super-culture". Other elements, although very important and perduring, but not as valued and projected, may be listed as "the sub-culture". In the Commonwealth Caribbean, because of its history, the super culture has been European: ideas, values and images from Africa have by and large, constituted our sub-culture. As some local and perspicacious social philosopher has described this scene: "White alright, brown hang around, black stay back".

At this stage, before going to give examples of how the sub-culture, because it is culture, has been treated by the Church over the years, I should like to backtrack a bit by looking at how the Church, in the widest sense of the word, has tried to deal with the question of culture per se over the past two millenia. I shall then return to the matter of the Afro-centric sub-culture and the Church in the Commonwealth Caribbean by looking briefly at the various forms of Christianity in Barbados, Trinidad and 
Tobago, Jamalca and ry own Bahamas.

What, now, has been the att1tude of the Church to culture, whether super or sub, over the years? Many attempts have been made at assessing this down the ages, the participants stretching from St. Paul to Paul T1llich. There, however, appears to be three basic approaches. The first has been that of delfying the culture, that is, making a religion of the dominant or super culture, and trying to define God in mono-cultural terms. Despite the lessons taught by the so-called GentileJewlsh controversy of New Testament times, where Salnt Paul had to fight against the temptation to sell Christianity to nonJews in an exclusively Jewlsh cultural package by submission to circumcision and the like, and later on by the alleged schismatics and heretics like the Donatists and Monophysites - who only really wanted to be Christians in a more Afrlcan than European way, the Church in Europe in its missionary expansion, once It had left Europe after the fifteenth century, insisted on delfying European culture as the equivalent of the Gospel. The distinction between what Don Cupitt (1975) has called Christlanity and Christendom was lost, and Indians and Afrlcan were expected to become Europeans in order to share in the saving work of Christ, so they thought. We in the Carlbbean know a great deal about what Cone (1975) has called the "honkyfisation of the divine". The second approach to culture, whether super or sub, has been that of denial and denfgration. This has been exemplifled by groups like some Gnostic sects in the early period and some very evangellcal sects in our day. In truth, monasticlsm at its worst has tended to reflect this from time to time. Simon Stylites and the Luddites have a lot in comon! The members of this school focus attention on the essential wickedness and transitoriness of the material world and all that it includes, espectally its cultural expressions. Its devotees, before the advent of $T . V$., were against the cinema and the theatre. Today they can still get very excited about dancing, playboy magazine and crlcket on Sundays. These latter day Platonists can see very little of value in "things which are seen". Finally, the third approach to culture has been that of neither deifying or denying, but of endeavouring to transform culture into a vehicle for conveying the humanising message of God-in-Christ as self-giving love. This has involved the attempt at making the culture a servant of the Gospel, not the exclustvely divine of demonic as the first two approaches may imp 1 The Church has had some success in doing this since the first Pentecost, and much of the kindness, altrulsm, carlng and sense of guilt over certain types of anti-social behaviour that we in the West take for granted today can be traced to this activity For example, no father today, however powerful or rich, would dare think of seling, imprisoning without trial, or killing his child. The Roman father, in exercise of potestas patris, before Christ, could do all of this in quite a routine way! The Church indeed has transformed the culture over the years, and we who are called Anglicans have played our part, if somewhat unevenly, in much of this in many parts of the world. Remember, Christopher Codrington, Richard Rawle, William W1lberforce, F. D. Maurice, William Temple and Desmond Tutu are all Anglicans!

The Church, then, has had to deal with the culture, both super and sub. At its best, it has tried to transform culture along Gospel Innes. At its worst, it has deifed or denied culture. This has been true of both the super and sub culture, with denial being the most common modus operand in the case of the sub. The following brief look at Christianity in four areas of our Caribbean will indicate that denial, however, has not always been the case, and that the approaches to the sub-culture have also involved the three elements of deification, denial and transformation.

We must, however, begin this section by trying to define what is the sub-culture in the area of the Caribbean with which we are dealing. This sub-culture, as stated earlier, is primarily African, not European or Astan or Amerindian as far as the Church is concerned.

What, then, are the characteristics of African culture? To be more specific, the question should relate to Bantu-African culture, for the roots of the Caribbean black diaspora seem more Bantu than Milotic or otherwise, although, as Diop (1973) has demonstrated, this distinction is not to be pressed too far in creating a total dichotomy between Africans north and south of the Sahara as colonial historians used to 
do - and not always on scientific grounds! Most soclologists on Africa agree that BantuAfrican culture is oral, commal and holistic. Ben Sidron, in Black Talk, (1971) draws attention to the princlple of what he calls "oralfty" among black Americans. By this he means the great emphasis on sound, whether spoken or created by mustcal

instruments, that is found among diaspora Africans because of their residual links with a culture in Africa that did not use the written word as the basis of communicating history and culture. Sidron in fact, concludes that the authentic black hero in North America is st111 the preacher or the road-band sideman with his skils in playing many musical instruments. Of course, Sidron's thesis may nct tell the whole story about the oral nature of African culture, but it does focus on the fact that the West Afrlca from which most of the slaves in this region came pald little attention to the written word. Its hero was the story-writer and contemplative. The griot and the drummer are the important chaps here! This oral society is inevitably very noisy, people like "to talk their talk" and "sing their song". It, because of the climate, does not have to hibernate for half of the year, and so its peoples abhor silence and physical confinement. Its climate also dispenses with the need to prepare for winter and so there is no real need to worry about clocks and calendars - if you $\mathrm{mix}$ up January with July you'11 st111 in Bantu-Africa make it to December. Th1s, alas, cannot be sald of Scandanavia! Long church services with Iffe will not bore folk from this culture when they meet Christianity later In their New World homes! As for the communal nature of African culture, this, too, results in part from the climate. People who spend all of their 11 ves outdoors are forced into belng outward-going. You must get to know your neighbour in this environment. Herskovits, (1970) in his Myth of the Negro Past, has noted the African penchant for hailing others all of the time. There is no greater insult than that of 1gnoring another person's presence in this type of soclety. Co-operative ventures are a part of this system, and so is resentment against any member of the group who seems to have more than his fair share of the communty's resources. A kest African proverb describes this attitude well when it states: "If you find bee-hive, it is good luck; if you find another it is better luck; if you find a third, it is witchcraft". No one needs three, and the comunity can't afford for one person to have three! This tendency was to be explolted by the new-world slave master later on, and remains a bane to black acceptance of their own in positions of wealth and authority to this very day!! Terms like "black crab syndrome" describe this frustrating tendency we11. This communal element can lead to the extended family, where obligations to cousins and aunts can outweigh those to wives and children. All of this seems like the Marxist utopla before Marx, doesn't $1 t$ ? We11, before one 18 tempted to Out-Marx Marx and Out-Mao Mao in Bantu-Africa one must remember that this communal spirit was Iimited to the clan and, at most, the tribe. There was nothing national about It in the sense that the more recent experiments in "communalism" have been. The part of Afrlcans in the slave trade should remove any naive ideas about Africans being different from other fallen sons of Adam In their selfishness and greed at the expense of others at times. This cavaet, however, does not deny the basic comunal nature of ancient and modern African culture, and mockers, Iike Shiva Naipaul, (1980) of Kaunda's "Afrtcan Humantsm" in Zambia, and Nyerere's "Ujamaa" in Tanzanla underestimate this force in the African psyche. The third characteristic of African culture is the hollstic. This is 11 nked with the commal. This part of the culture looks at life in its totality, it does not deal, in the Cartesian manner, with "either or", it prefers "both and". It does not separate the invisible world from the visible. It links Sunday with Monday, the living with the dead, yesterday with today. Sidron (1971) talks of "not distinguishing between work and play, 11fe and art". This what Mit1 (1969) characterises as Zamani-Sasa mindset is very practical, and what is not utilitarian is not valued. It also does not hoard easily, including knowledge, and if it has anything it is to be used. Black intellectuals have been teased for liking "big words". This is true, for the African psyche does not like unusable items, even words like "perspicactous". "If you have 1t, flaunt 1t, brother!" The same 18, for example, true of black cricketers. If you can late-cut, legglance, or cover-drive, then do 80 , irrespective of the kind of pitch, the state of the match or the length of the bal1! Some cynical wit, at this time, 
may want to add, "If you can play cricket, play 1t, man, even in that last of the plantations that we call South Afrlca". On a more serious, if less controversial, note, the African culture from which our contemporary Caribbean sub-culture is derlved was oral, cammual and hollstic. Years ago, it was unfashionable, even among black people, to admit that this African culture had survived the Middle Passage. When Melville Herskovits, in the forties, wrote his seminal Myth of the Negro Past, blacks were foremost among his critlcs in denylng that mother Africa was still in their bones. The vogue enjoyed by this book today among dlaspora blacks Indicates how much things have changed. Pride in Africa and ease in using the word "black" as a positive adjective by black people have gained much ground in the last decade or 80 . There are, of course, still some who prefer words like "coloured" and are emotionally threatened by women wearing Afros, not to mention dreadlocks, but this should not be surprising in view of recent and present history. The existence today of the financial syster called susu or asue or meeting-turn, a game called warl and the Oeah-man shows that mother Africa did survive the MIddle Passage - and how!

Let us now look at how the Church has trled to deal with the ideas, values and Images which constitute the sub-culture in the Comonwealth Caribbean. As Indicated earlier, I should like to adopt the case-study method by looking at the situation in four territorles, namely Barbados, Trinidad, Jamaica and the Bahamas. I shall use as my yardstick the princlples of deffication, denfal and transformation as delineated above in the discussion of the Church's general approach to culture, whether super or sub, over the years.

How, then has the Church in Barbados dealt with the African sub-culture of its people? It definitely has not delfed it! Little England could not do this. An extra economic and political hundred years on the plantation because of the scarcity of land after 1834, and an established Anglican Church long after the British Government had stopped paying for overseas bishops and priests made such an approach imposstble. There was, however, not a complete denlal either. A certain amount of transformation, Intentional and otherwise, has taken place. Any religious group, whether Anglican or Plymouth Brethren, must have good preaching and good singing to appeal to the Barbadian masses. The older "B'dian" clergy, many from the planter class sensed this, and encouraged music and rhetoric as vehicles for bringing the people to the Lord. They realised that the former slaves did not like too much silence, they wanted to partictpate and to be both seen and heard. The enthusiastic involvement in saying the prayers with the priest in the new liturgies of today is in the same vein. The other denominations have done the same, and the more exotic ones have taken the "orality principle" to the limit with drums and tambourines. The African need to have an holistically practical religion has also affected the mission of all the denominations in Barbados. In the older days, practical salvation lay in book-learning and the successful church had to run schools. The Anglican advantage in its state connection gave it a lead that persists to this very day. The religious group that runs the schools, manages the almhouses, and has an entree to the plantation house has an irrestible appeal to the African personality. The present growth in Barbados of the smaller religious groups with access to Yankee dollars and stress on faith-healing may in no smal1 way again reflect, the sub-culture's need to have a religion that feels both body and soul. The sub-culture's love-hate relationship with the old white slave-master could also be a factor here, for the most successful of these groups do have a white man at the head. Because of Barbados' social history, the transformation approach has not been as dominant as in other places, but it, as noted above, has taken place to some extent in "Bim" also.

In Trinidad and Tobago the Church appears to have followed more of the transformation path than in Barbados. The Euro-centric colonial super-culture has also ruled out deification. The Southern-EuropeanCatholic roots of this culture also worked against denial, for Catholicism, in its inherent Aristotelfanism, is basically not afraid of playing around with the physical world. It has therefore been easier in Trinidad to accept the sub-culture's love of noise, spectacle and music, and to use them in the service of the Lord. Catholicism in its present form is the most nonEuropean of all that is associated with 
European culture today, anyway. The cassock, the incense and the candles are dramatic reminders to all that Catholicism's roots are in the South. And what is South of Italy? AFRICA, of course! Consequently, Blacks in Irinfdad and Tobago have found it easy to enjoy being catholics, whether Roman or Anglo. The calypso and carnival both $c$ ne from the south, not the north! Trinidad and Tobago have also been the scene of a more radical transformation than that found among Cathollcs and High church Anglicans. It has had the Baptists and other Pentecostal relfgious expressions in a way not found in Barbados. Even left of these groups have been the Shango and Spiritual Baptists; use of the sub-culture in the service of the Gospe1. The comonal spirit as expressed in greetings like "brother" and "sister" for the membership, the self-help schemes of these religious families, the almost obeah-man style and power of the charismatic leaders, all reflect the Africa of old.

It is, however, In Jamaica that the attempts at avolding the denial of the African subculture have been most common. This should not be surprising, for it is Jamaica that has also produced the two great black Ms, the Maroons and Marcus Garvey. In short, Jamaica, because of its size and population, hss had to deal with the African presence in a way that other territories did not - and this presence, as Aptheker's (1970) study on the hundreds of slave rebellions in the U,S.A. reveals, was not a docile one. It is, therefore, in Jamaica that an attempt at delfylng, yes, "deify'ng", the sub-culture has taken place. The participants in this exerclse have belonged to all of the regular denominations, and in so dolng they have formed a brand new church. This is what Rastafarianism at its best, in opinion, is all about. The genuine I-and-I man, not the imposter or trouble maker, is the dramatic affirmation of the ideas, values and Images of the Bantu-African man. The new Jerusalem is Ethiopia; the Christ or Messtah is the deceased Emperor, Ras Tafar1; the place of exile and dispersion is the new Babylons of New York, Ringston, Bridgetown and Toronto; the most popular psalmists of the cultus are Marley, Tosh and Yellowman. As you may have noted, this attempt at restating the Christian Messianic message in African terms by many former orthodox christians has led to the abandonment of the traditional Christian heroes and categories to make 1 ts case - all in angry reaction to the persister: Eurocentric deification of European culture among nonEuropean peoples for the past three hundred years. The Rastas, like the Donatists and Monophysites of old, have become heretics in order to make their point that God is not a honky: He is a nigger! Both the "honky" and the "nigger" are, of course, distortions of the authentic white and black man. The Rastas indeed have gone beyond this in their frustration with Eurocentric Christendom, not Christianity, remember, and have tried to replace Jesus of Nazareth with Selasie of Ethiopia, incense with ganga, the monastic tonsure with dreadlocks, abstinence from meat with rejection of all flesh. In Rastafarlanism, the African sub-culture is deifed with all the arrogance, intolerance and bombast that delfication entalls, and the tables are turned on the plantation preachers from Europe! The presence of the Ethioplan Orthodox church in Jamaica is of a plece with Jamaica's attempt through Rastafar1anism to make the sub-culture a religious force in the people's lives in an African dress. It is no accident that this Christian church is found only in Jamalca to any great extent at this time. The other more or less orthodox denominations in Jamalca have, in varying degrees, tried to transform the sub-culture. The Anglican, Catholics, United Church and Moravians have paid attention to the vibes of the African sub-culture, whether oral, comunal or holistic, by providing ceremonial, good preaching, good choirs, day schools and clinics over the years. The Baptists of both major groups have encouraged even more use of the sub-culture in their polity and customs. It is only they that provided the slave freedom fighters like Paul Bogle, but they also, after emanc1pation, helped the slaves to found new villages and acquire co-operative plantations. The Baptists have tended to drew their membership malnly from the black population, and this has made their part of the church in Jamaica a more radical, transforming agent. This type of denomination demands good sounds, whether from the preacher or from the cholr. It is very democratic, and the people will not tolerate leaders who get too "great" or "biggoty". The leader who is too "great" will not last long, insplring fear and resentment not love. That's all African sub-culture! The situation in the Bahamas, my turf, is very similar to that in Jamatca, for we 
northerners have been influenced by Uncle Sam long before Seaga and Reagan! Because of this, we both have many Baptists. The main difference between us and Jamaica would be the presence of the Ethioplan orthodox church and long-standing organlzed Rastafarlanism. Our way, too, has been that of transformation rather than delfication or complete denial of the sub-culture. Our so-called maln-line denominations have had to come to terms with the sub-culture's need for good sluging, dramatic preaching or elaborate ceremontal. HIgh church Anglicans, like myself, have the lmpossible task trylng to do al1 three! Other denominations, with thelr drums, electric guitars and shouting preachers, have transformed the sub-culture in this way. All denominations have been required to provide for both the spiritual and material needs of the membership, and denominations which do not do this find the going rough. When the Anglicans returned to runnting a High School in 1947, the argument that had most welght with our people was that the Roman Catholics had one! Our Baptists and Pentecostals were the leaders in the move towards majorlty rule and independence in the $1960 \mathrm{~s}$ and 708 , and today the Bahamas Christian Council is supposed to have an opinfon on every fssue that arises in our young nation. The African sub-culture does belleve that Sunday and Monday are really the same, and that the holy day should be the holiday.

The foregoing has been a short atterpt to show how the Church has been unable to avold dealing with the African sub-culture with its emphasis on the oral, commal and holistic. The process followed, by and large, has been that of endeavouring to transform the subculture rather than denying it. Deffication was out of the question apart from a minorlty in Jamalca. The success of this process has varied. What, however, is important is that the Church in the Caribbean continues to recognize the power of all culture, super and sub, and to enlist it in the service of spreading the Good News abort Jesus Chrigt. The present sub-culture, because of majorlty rule and independence, is fast becoming the main force in the moulding of the new superculture, and it is the Church's job to see that the mistakes of the past in denying Afro-centric do not happen to the Euro-centric and the Astano-centric; for Caribbean K.K.K. Skin-heads, National Fronts, Western Guards, and
Moslem Brotherhoods will be the end result for all, as people of European and East Indian descent react violently to being defined out of the culture by those of African descent. The church must constantly remind the commity that the white Bahamian is just as Bahamian as the black! Pray, then, that the Church, in all its denominations, continues to struggle to transform all cultures, including new Afro-Euro-Astan that is developing in our midst as we beat goombay drums, drink Scotch whisky and eat roti and curried goat throughout our island homes from day to day. Rex Nettlefords' "new people" are indeed here to stay!!

$1_{\text {Lecture given at Holy Cross Church, }}$ St. John's Barbados on February 9 th, 1983, as part of a series to commenorate the 150 th anniversary of the church where Codrington College students worship and practise "preaching to a live congregation". 


\section{REFERENCES}

Aptheker, Herbert, American Negro Slave Revolts; International Publisher,

Cone, James, The God of the Opressed; The Seabury Press, New York, N.Y., 1975 .

Cox, Harvey, The Seduction of The Spixit; Simon \& Schuster, New York, New York, 1973.

Cupitt, Don, The World to Come; S. C. M. Press, London, England.

Diop, A., The African Origin of Egypt; The Beacon Press, Boston, Massachusetts, 1973.

Herskovits, Melville J., The Myth of the Negro Past; The Beacon Press, Massachusetts, 1970.

Mbiti, John S., African Religions \& Philosophy; Heinemann, London, England, 1969 .

Mitchell, David I., With Eyes Wide Open; Bridgetown, Barbados, 1973.

Naipaul, Shiva, North of South; Penguin Books Limited, Middlesex, England, 1980.

Owens, Joseph, Dread: The Rastafarians of Jamaica; Sangster, Kingston, Jamaica, 1976 .

Sidron, Ben, Black Talk; Simon \& Schuster, New York, N.Y., 1973.

. Tillich, Paul, Systematic Theology; University of Chicago Press Ill., 1951. 